\title{
Geologic Mapping and Mineral Resource Assessment of the Healy and Talkeetna Mountains Quadrangles, Alaska Using Minimal Cloud- and Snow-Cover ASTER Data
}

Bernard E. Hubbard, Lawrence C. Rowan, Cynthia Dusel-Bacon, and Robert G. Eppinger

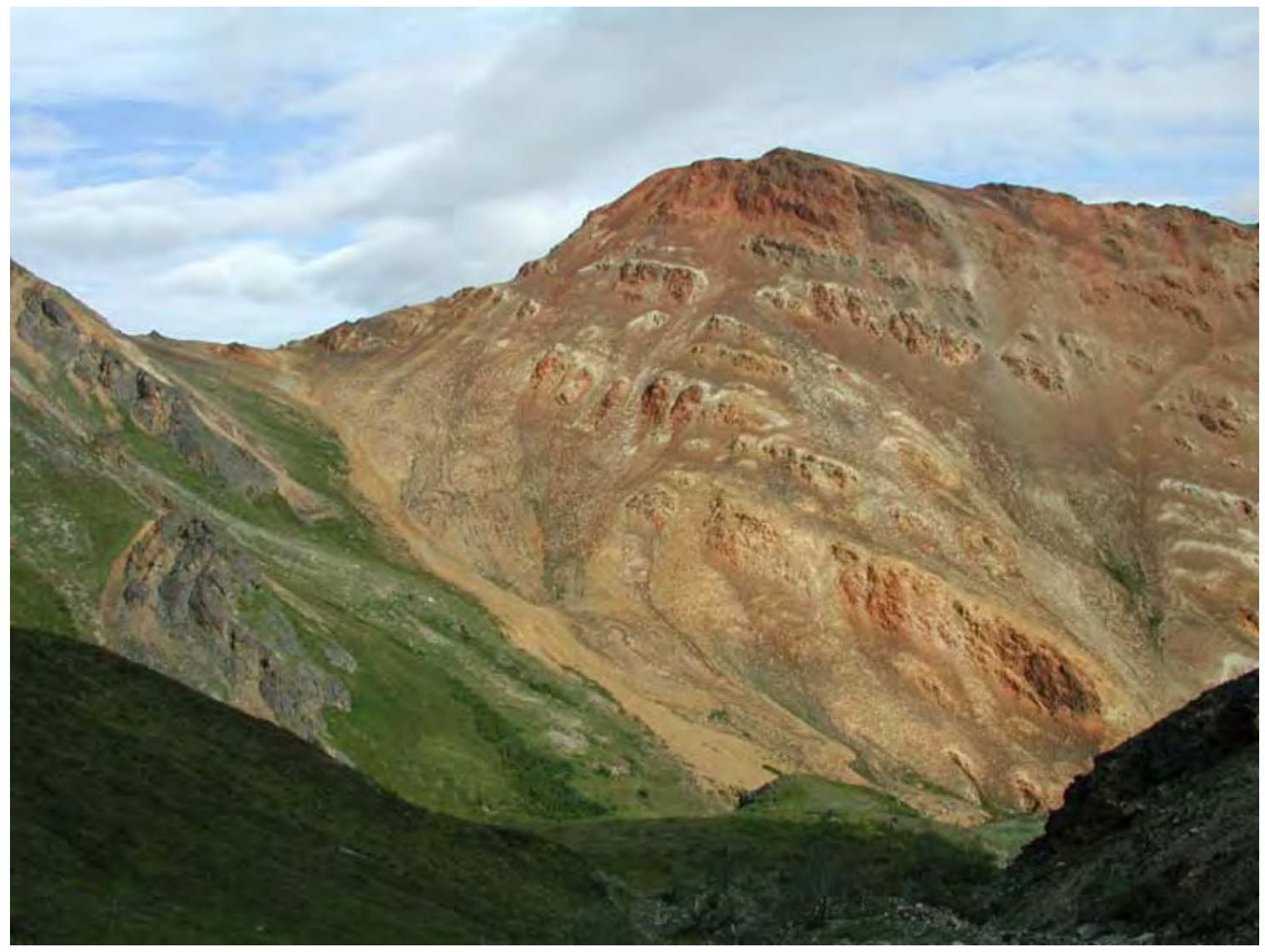

Open-File Report 2007-1046

U.S. Department of the Interior

U.S. Geological Survey 


\title{
U.S. Department of the Interior DIRK KEMPTHORNE, Secretary
}

\author{
U.S. Geological Survey \\ Mark D. Myers, Director
}

U.S. Geological Survey, Reston, Virginia 2007

Revised and reprinted: 2007

For product and ordering information:

World Wide Web: http://www.usgs.gov/pubprod

Telephone: 1-888-ASK-USGS

For more information on the USGS - the Federal source for science about the Earth, its natural and living resources, natural hazards, and the environment:

World Wide Web: http://www.usgs.gov

Telephone: 1-888-ASK-USGS

Suggested citation:

Hubbard, B.E.., Rowan, L.C., Dusel-Bacon, C., and Eppinger, R.G., 2007, Geologic

Mapping and Mineral Resource Assessment of the Healy and Talkeetna Mountains Quadrangles, Alaska Using Minimal Cloud- and Snow-Cover ASTER Data: U.S. Geological Survey Open-File Report 2007-1046.

Any use of trade, product, or firm names is for descriptive purposes only and does not imply endorsement by the U.S. Government.

Although this report is in the public domain, permission must be secured from the individual copyright owners to reproduce any copyrighted material contained within this report. 
Cover: Photograph of Red Mountain volcanogenic massive sulfide deposit, Bonnifield mining district, Healy quadrangle, Alaska.

Photograph taken by Robert G. Eppinger, U.S. Geological Survey, Denver, Colorado, on the afternoon of July 24, 2003. The bedrock in the view is all Devonian to Mississippian Mystic Creek Member of the Totatlanika Schist. The lack of tundra vegetation on the right side of the photo is directly related to the highly acidic, metalliferous nature of the rock and soil being shed from Red Mountain. 


\section{Contents}

Abstract

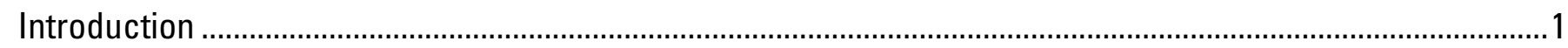

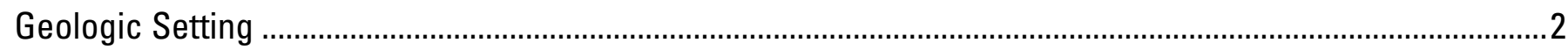

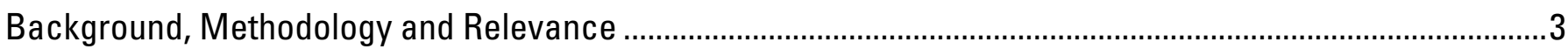

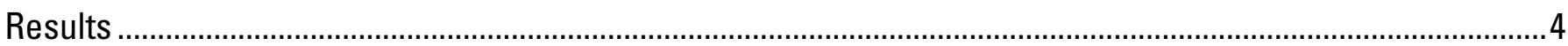

Host-Rock Mapping Using ASTER TIR Data ……………..........................................................................

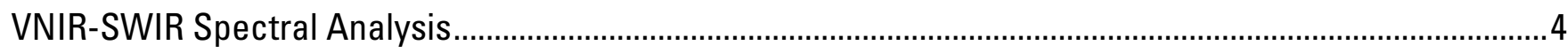

Alteration Mineral Maps of Known and Undiscovered VMS and Porphyry Deposits ..................................... 4

GIS Analysis and Assessment Comparison .........................................................................................

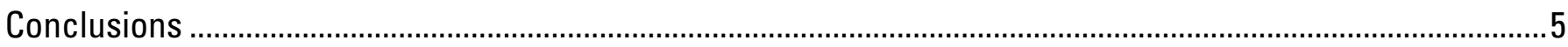

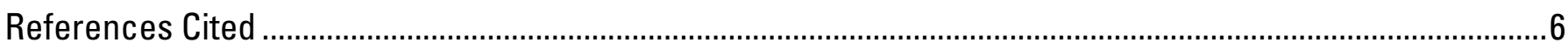

\section{Figures}

1. Location map of the Healy and Talkeetna Mountains Quadrangles, Alaska. ...............................................10

2. Litho-tectonic terrane boundaries superimposed on ASTER data swath. .......................................................11

3. Metamorphic geologic map of ASTER swath coverage. ...........................................................................12

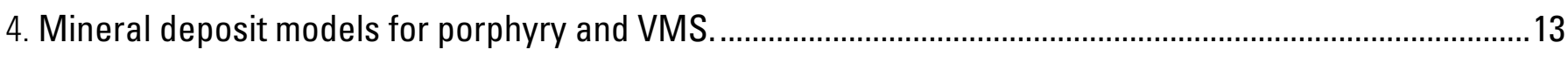

5. Lithologic mapping results and spectral analysis using ASTER five-band TIR spectra.................................14

6. Comparison of nine-point ASTER VNIR-SWIR image spectra and spectral library data................................16

7. Mineral mapping results showing selected VMS and porphry type hydrothermal alteration zones...........17

8. Mapping results showing known and potential VMS deposits of the Healy and Talkeetna Mountains quads mapped using ASTER superimposed on permissive tract boundaries.........................................18 


\title{
Geologic Mapping and Mineral Resource Assessment of the Healy and Talkeetna Mountains Quadrangles, Alaska Using Minimal Cloud- and Snow-Cover ASTER Data
}

\author{
By Bernard E. Hubbard, Lawrence C. Rowan, Cynthia Dusel-Bacon, and Robert G. Eppinger
}

\begin{abstract}
On July 8, 2003, ASTER acquired satellite imagery of a $60 \mathrm{~km}$-wide swath of parts of two 1:250,000 Alaska quadrangles, under favorable conditions of minimal cloud- and snow-cover. Rocks from eight different lithotectonic terranes are exposed within the swath of data, several of which define permissive tracts for various mineral deposit types such as: volcanic-hosted massive sulfides (VMS) and porphyry copper and molybdenum. Representative rock samples collected from 13 different lithologic units from the Bonnifield mining district within the Yukon-Tanana terrane (YTT), plus hydrothermally altered VMS material from the Red Mountain prospect, were analyzed to produce a spectral library spanning the VNIR-SWIR $(0.4-2.5 \mu \mathrm{m})$ through the TIR $(8.1-11.7 \mu \mathrm{m})$.
\end{abstract}

Comparison of the five-band ASTER TIR emissivity and decorrelation stretch data to available geologic maps indicates that rocks from the YTT display the greatest range and diversity of silica composition of the mapped terranes, ranging from mafic rocks to silicic quartzites. The nine-band ASTER VNIR-SWIR reflectance data and spectral matched-filter processing were used to map several lithologic sequences characterized by distinct suites of minerals that exhibit diagnostic spectral features (e.g. chlorite, epidote, amphibole and other ferrous-iron bearing minerals); other sequences were distinguished by their weathering characteristics and associated hydroxyl- and ferric-iron minerals, such as illite, smectite, and hematite.

Smectite, kaolinite, opaline silica, jarosite and/or other ferric iron minerals defined narrow $(<250 \mathrm{~m}$ diameter) zonal patterns around Red Mountain and other potential VMS targets. Using ASTER we identified some of the known mineral deposits in the region, as well as mineralogically similar targets that may represent potential undiscovered deposits. Some known deposits were not identified and may have been obscured by vegetation- or snow-cover, or were too small to be resolved.

\section{Introduction}

On July 8, 2003, the Advanced Spaceborne Thermal Emission and Reflection Radiometer (ASTER) sensor aboard the TERRA satellite acquired a 60-km-wide orbital swath of data covering parts of the 
Healy and Talkeetna Mountains 1:250,000 quadrangles (fig. 1) and areas beyond Anchorage and the populated Matanuska Valley. Figure 1 illustrates the extent of the ASTER data coverage used in this study, which was acquired under unusually low-cloud and -snow cover conditions.

Mineral resources exploration throughout much of the state has been hampered by the large geographic distances, lack of roads and paucity of detailed geologic maps at 1:63,360 scale or less. This leaves a large part of the state with possible undiscovered, potential metallogenic resources. The purpose of this paper is to show the utility of ASTER for lithologic mapping which can be used to better constrain permissive tracts and for targeting hydrothermal alteration zones related to potential undiscovered mineral occurrences. The Healy and Talkeetna Mountains quadrangles are ideal places to develop a remote sensing methodology for mineral resource assessment because: 1) the area hosts a number of mining districts that have either presently or in the past produced such commodities as copper, zinc, silver, lead, gold and molybdenum; and 2) detailed geologic maps ( $<1: 63,360$ scale $)$ exist for a number of the 15 ' quadrangles covered by our swath of data (see labeled sub-quads in fig. 1 ).

\section{Geologic Setting}

Rocks from eight different lithotectonic terranes are covered within the swath of ASTER data (fig. 2). These terranes range in composition from oceanic crust affinity to island-arc and flysch sequences, accreted during Mesozoic orogenic events (Foster et al., 1994; Nokleberg et al., 1994a), to parautochthonous continental margin metasedimentary and metaigneous rocks (Dusel-Bacon et al., 2004). Most of the rocks have been regionally metamorphosed to grades ranging from prehnitepumpellyite to amphibolite (fig. 3), some of which contain characteristic minerals that can be mapped using spectroscopic remote sensing methods (e.g. chlorite, epidote, talc, biotite, amphiboles and serpentine minerals). Several important VMS deposits are located within the Yukon-Tanana (e.g. fig. 2 - yellow-colored "mine" symbols), and their metallogenesis is discussed by Nokleberg et al. (1994b) and Newberry et al. (1997).

The Healy and Talkeetna Mountains quads contain a variety of rocks ranging from mafic meta-volcanic rocks to felsic meta-volcanic rocks, with a range of intermediate compositions (Csejtey et al., 1978; 1986; 1992 and references therein). Post- and syn-metamorphic plutonic rocks with a wide range of compositions (e.g. quartz-diorite, tonalite, granite, granodiorite, trondhjemite and adamellite) are also widespread. Sedimentary and meta-sedimentary rocks such as limestones, marbles, conglomerates, argillites, shales, siltstones, sandstones, phyllites, pelitic schists, quartzites and chert deposits are also exposed within the various accreted terranes shown in figure 2. 1:250,000 scale geologic maps compiled by Csejtey et al., $(1978 ; 1986 ; 1992)$ include earlier, more detailed maps covering the labeled sub-quads shown in figure 1.

Felsic meta-volcanic and meta-volcaniclastic rocks are important host rocks for Kuroko-type VMS deposits (see fig. 4). Mafic meta-volcanic and meta-volcaniclastic rocks typically host Besshi-type VMS deposits (Cox and Singer, 1986 -deposit model 24b), which are distinct from the Cyprus-type VMS deposits associated with ophiolites (Cox and Singer, 1986 - deposit model 24a). Differences in host rock composition and metamorphic grade lead to differences in the phyllosilicate mineral assemblages associated with VMS deposits, potentially providing a remote sensing basis for their discrimination. For example, several of the VMS deposits mapped using ASTER are associated with greenschist facies metamorphic host rocks (compare figs. 3 and 8 covering the same scale). Such rocks show enhanced crystallinity of clay minerals, both associated with hydrothermal alteration, and within 
the metamorphic rock groundmass (e.g. McLeod and Stanton, 1984; McLeod, 1985; 1987; McLeod et al., 1987). Higher metamorphic grades such as amphibolite will alter clay minerals such as kaolinite unless they are replenished by supergene alteration processes.

\section{Background, Methodology and Relevance}

Mineral resource assessments have traditionally been done in three-parts by (e.g. Singer, 1992): 1) delineating areas favorable and/or permissive for a deposit type(s) based on geologic map data, location of known occurrences, exploration information, geophysical and geochemical data; 2) using grade and tonnage models for estimating the size and production potential of each tract; and 3) estimating the number of undiscovered deposits for each deposit type assessed. In the case of the Healy and Talkeetna Mountains quads, earlier field-based mineral resource assessments either show the mapped distribution and locations of mines, prospects and sampled occurrences (including downstream placer deposits) (e.g. Cobb, 1972; Clark and Cobb, 1972; Csejtey and Miller, 1978) and/or permissive tracts delineated based on the 1:250,000 scale geologic maps for these two quads (e.g. Singer et al., 1978; Cox et al., 1989). In particular, Newberry et al., 1997 presents a comprehensive summary of VMS deposits in the area and their metallogenesis.

Based on modeled mineral deposit characteristics such as size and scale (which also influences grade and tonnage), hydrothermal alteration patterns (fig. 4), host rock lithology, gangue minerals and weathering characteristics (e.g. Cox and Singer, 1986), we use ASTER mapping results to highlight known and potentially undiscovered VMS and porphyry deposits. The results are then used to illustrate how favorable and/or permissive tracts for VMS deposits can better be delineated when including such data. Figure 4 illustrates key differences in size and hydrothermal alteration patterns between VMS and porphyry deposit types, which can exploited using remote sensing data such as ASTER.

ASTER measures reflected radiation in three bands between 0.520 and $0.860 \mu \mathrm{m}$ (visible-near-infrared region - VNIR) and in six bands from 1.00 to $2.43 \mu \mathrm{m}$ (short-wave infrared region - SWIR), with 15-m and 30-m spatial resolution, respectively (Fujisada, 1995). In addition, ASTER measures emitted thermal radiation in five bands in the 8.125- to 11.650 - $\mu \mathrm{m}$ wavelength region (thermal-infrared region TIR) at 90-m resolution (Fujisada, 1995). Both standard calibrated ASTER data products (VNIR-SWIR reflectance, TIR emissivity, and TIR decorrelation stretch) and/or their equivalents were used in this study (see Rowan et al., 2003; Rowan and Mars, 2003). Briefly, igneous rock types and alteration minerals were mapped based on image spectral endmembers derived through principal component analysis (e.g. Green et al., 1988; Boardman et al., 1995) of the five TIR and nine VNIR-SWIR bands of ASTER, respectively. These spectral endmembers (e.g. figs. 5f, 6a and 6b) were used as reference spectra in subsequent matched-filter image classification procedures (Harsanyi and Chang, 1994). The standard decorrelation stretch image product (figs. 5a and b) shows ASTER TIR bands 10, 12, and 13 displayed as blue, green and red respectively. Decorrelation stretch images are used to enhance the brightness variations between TIR bands related to compositional differences and emissivity, while suppressing correlated inter-channel brightness values dominated by radiant temperature (Gillespie et al., 1986). 


\section{Results}

\section{Host-Rock Mapping Using ASTER TIR Data}

Within the Yukon-Tanana and Pingston terrane rocks, linear enhancement of the TIR-decorrelation stretch data shows a variety of lithologic compositions ranging from the mostly mafic (blue-colored, fig.5b subset), intermediate (purple and magenta shades, fig. 5b subset), and quartz-rich rocks such as granitic intrusions and/or quartzites (red-colored, fig. 5b subset). Several of these rock types are grouped together into formations at the 1:250,000 scale (e.g. Totatlanika Schist - Csejtey et al., 1992), but shown as distinct lithological members in the more detailed 1:63,360 geologic maps (e.g. from oldest to youngest: Moose Creek, California Creek, Chute Creek, Mystic Creek, and Sheep Creek members - Wahrhaftig, 1970a; b; Gilbert, 1977). Generally, rocks of the YTT terrane, which lies north of the Hines Creek fault, and rocks from the Pingston terrane, which lies between the Hines Creek and McKinley faults, appear to be more silicic in composition than exposed rocks of the Wrangellia terrane, south of the McKinley fault (figs. 2 and 5a).

Overall, YTT rocks display a much greater range and diversity of felsic and mafic mineral compositions than rocks from the other terranes, which appear more subdued in the decorrelation stretch image of the larger swath (fig. 5a). An alternative possibility is that rocks from the other terranes south of the YTT, PN and MK (see also fig. 2) may be more vegetated and/or snow-covered. VNIR-SWIR and TIR spectral measurements were done on a diverse suite of 13 YTT rock samples collected from the Bonnifield mining district. TIR spectra of three of these samples are shown in figure 5d along with a quartzite spectrum extracted from a spectral library. There is good agreement in spectral shapes between spectra of representative field samples and corresponding image spectra from the same locations of rock units ranging from felsic to mafic (figs. $5 \mathrm{~d}$ and e respectively).

Because mixtures of snow (or vegetation) with rocks negatively affects the utility of TIR decorrelation stretch images, adequate discrimination of the intermediate-composition and silicic rocks of the Peninsular terrane from the mostly mafic rocks of the Wrangellia terrane, required use of spectral endmember and "unmixing-based" classification methods (fig. 5c and corresponding spectral endmembers shown in fig. 5f). A more detailed comparison between the ASTER mapping results and geologic maps at the 1:250,000 and 1:63,360 scales will be presented in a forthcoming publication.

\section{VNIR-SWIR Spectral Analysis}

Spectral analysis of fine-grained rock and soil samples collected at Red Mountain confirms the presence of kaolinite, illite-muscovite, smectite and goethite. Also, a variety of ferric-iron and aluminum oxyhydroxide and sulfate mineral precipitates are found in and around the streams draining the mountain, reflecting natural acid-rock drainage conditions within a pristine (unmined) VMS deposit (Eppinger et al., 2007). Generally, there is good agreement in spectral shapes between image endmembers used in the mapping results shown in fig. 7 and spectral library spectra representing pure mineral types (figs. 6a, $\mathrm{b}$ and figs. $6 \mathrm{c}, \mathrm{d}$ and e respectively).

\section{Alteration Mineral Maps of Known and Undiscovered VMS and Porphyry Deposits}

Figure 7 shows the resulting mineral maps generated using 9-band ASTER VNIR-SWIR data and spectral matched-filtering methods (see fig. 6 for representative mineral endmembers). Large areas of the upper two scenes of the ASTER mosaic (fig. 7 - large top overview map) were classified as 
containing ferric-iron minerals, chlorite and/or epidote, and muscovite and/or illite. The chlorite and/or epidote are $\mathrm{Fe}, \mathrm{Mg}-\mathrm{OH}$ minerals that commonly occur in the predominantly greenschist and prehnitepumpellyite facies of metamorphic rocks throughout the area (see fig. 3 for corresponding metamorphic facies locations). Muscovite and/or illite can occur either as primary minerals in the groundmass of igneous and metamorphic rocks, sericitic hydrothermal alteration zones, or as the weathering product of K-rich rocks.

Figures 7a-c show alteration mineral zones mapped at a scale of 1:25,000 for A) Red Mountain and WTF massive sulfide deposits, B) Anderson Mountain massive sulfide deposits, and C) area of possible alunite occurrence at Nenana Mountain in rocks mapped as Tertiary granites and Quaternary Yanert Glacier moraines. The Nenana Mountain and Yanert Glacier distribution could represent argillic and propylitic zones of a porphyry copper deposit as depicted in fig. 4a, which differs in scale and mineralogy from what is expected in hydrothermal alteration zones associated with VMS deposits (e.g. fig. 4b).

\section{GIS Analysis and Assessment Comparison}

Numerous ( 192) potential VMS deposits were mapped using ASTER and their distribution is shown in figure 8 . Their identification was based on small-scale $(\sim 100-200 \mathrm{~m})$ mineral zoning patterns between hydrous silica, jarosite, kaolinite, and smectite, which graded into background rocks dominated by ferric-iron, chlorite and sericite (e.g. fig. 4b and 7). Other deposit types with discernable alteration mineral patterns such as porphyry, ferric-iron gossans, and propylitic alteration associated with epithermal- and polymetallic-veins are subject to further interpretation and thus were not included in the GIS analysis. In general, potential porphyry deposits defined by larger scale $(>1 \mathrm{~km})$ argillic and propylitic alteration zones (see fig. 4a) were mapped in parts of the McKinley terrane and Wrangellia terrane related to Cretaceous and/or Tertiary plutons (see fig. 3). Epithermal- and polymetallic-vein deposits have alteration patterns similar to porphyry deposits (fig. 4a), but with argillic zones that are commonly too small $(<10 \mathrm{~m})$ to be mapped by remote sensing. In some cases the detection of propylitic alteration zones along lineaments may aid in the recognition of polymetallic vein deposits (e.g. Mars and Rowan, 2006).

Notably, several of the ASTER mapped deposits cluster along the edge of the scene (e.g. within the undelineated Kahiltna terrane rocks) or outside the boundaries of previously drawn permissive tracts. This suggests that remote sensing mapping using multispectral data such as ASTER can aid in future mineral resource assessments by improving how and where permissive and/or favorable occurrence tracts are drawn. In this case, the VMS permissive tracts shown in figure 8 are based on the most recent national assessment completed in 1998 (USGS, 2002). Known VMS mines, prospects and occurrences in the Healy and Talkeetna Mountains quads, were derived from Alaska Resource Data Files compiled by Stevens (2001) and Rogers and Schmidt (2003). However, these data files do not contain all of the mines, prospects and occurrences mapped during previous assessments (e.g. Cobb, 1972; Clark and Cobb, 1972; Csejtey and Miller, 1978; Singer et al., 1978; Cox et al., 1989).

\section{Conclusions}

In this study, we show the utility of ASTER as an exploration tool for mapping potential occurrences of VMS and porphyry deposit types based on the deposit model characteristics such as host rock lithology and weathering characteristics, deposit size and scale, and hydrothermal alteration zonation patterns as described in Cox and Singer (1986). Nearly 200 known and potentially undiscovered VMS deposits 
were mapped based on these deposit model criteria and image processing and spectral analysis of ASTER data. The results of this study show the utility of remote sensing, and in particular ASTER, for use in future mineral resource assessments. For example, such data is useful for the recognition of unknown deposits, definition of favorable and/or permissive tracts, and for providing basic rock composition data in geologically poorly known areas. Further research is needed to test the utility of such data in terranes covered to varying extents by vegetation.

\section{References Cited}

Beikman, H.M., 1980, Geologic Map of Alaska, 2 sheets, scale 1:2,500,000.

Boardman, J.W., Kruse, F.A., and Green, R.O., 1995, Mapping target signatures via partial unmixing of AVIRIS data: Proceedings of the Fifth JPL Airborne Earth Science Workshop, JPL Publication 9501: 23-26, Jet Propulsion Laboratory, Pasadena, CA.

Clark, A.L., and Cobb, E.H., 1972, Metallic mineral resources map of the Healy Quadrangle, Alaska: U.S. Geological Survey Miscellaneous Field Studies Map MF - 394, scale 1:250,000.

Cobb, E.H., 1972, Metallic mineral resources map of the Talkeetna Mountains Quadrangle, Alaska: U.S. Geological Survey Miscellaneous Field Studies Map MF - 370, scale 1:250,000.

Cox, D.P., and Singer, D.A., 1986, Mineral deposit models: U.S. Geological Survey Bulletin 1693, $379 \mathrm{p}$.

Cox, D.P., Light, T.D., Csejtey, Béla, Jr., and Campbell, D.L., 1989, Mineral Resource Assessment Map of the Healy Quadrangle, Alaska: U.S. Geological Survey Miscellaneous Field Studies Map MF 2058-A, scale 1:250,000.

Csejtey, Béla, Jr., Nelson, W.H., Jones, D.L., Siberling, N.J., Dean, R.M., Morris, M.S., Lanphere, M.A., Smith, J.G., and Silberling M.L., 1978, Reconnaissance geologic map and geochronology, Talkeetna Mountains quadrangle, northern part of Anchorage quadrangle, and southwest corner of Healy quadrangle, Alaska: U.S. Geological Survey Open-file Report 78-558-A, incl. scale 1:250,000 map.

Csejtey, Béla, Jr., and Miller, R.J., 1978, Map and table describing metalliferous and selected nonmetalliferous mineral deposits, Talkeetna Mountains Quadrangle, Alaska: U.S. Geological Survey Open-file Report 78-558-B, incl. scale 1:250,000 map.

Csejtey, Béla, Jr., Mullen, M.W., Cox, D.P., Gilbert, W.G., Yeend, W.E., Smith, T.E., Wahrhhaftig, C., Craddock, C., Brewer, W.M., Sherwood, K.W., Hickman, R.G., Stricker, G.D., St. Aubin, D.R., and Goerz III, D.J., 1986, Geology and Geochronology of the Healy quadrangle, Alaska: U.S. Geological Survey Open-file Report 86-396, incl. scale 1:250,000 map (superseded by Csejtey et al., 1992).

Csejtey, Béla, Jr., Mullen, M.W., Cox, D.P., and Stricker, G.D., 1992, Geology and Geochronology of the Healy quadrangle, South-Central Alaska: U.S. Geological Survey Miscellaneous Investigations Series Map I-1961, 63 p., 2 sheets, scale 1:250,000. 
Dusel-Bacon, C., Csejtey, Béla, Jr., Foster, H.L., Doyle, E.O., Nokleberg, W.J., and Plafker, G., 1993, Distribution, facies, ages, and proposed tectonic associations of regionally metamorphosed rocks in east- and south-central Alaska: U.S. Geological Survey Professional Paper 1497-C, 73 p., 2 sheets, scale $1: 1,000,000$.

Dusel-Bacon, C., Wooden, J.L., and Hopkins, M.J., 2004, U-Pb zircon and geochemical evidence for bimodal mid-Paleozoic magmatism and syngenetic base-metal mineralization in the Yukon-Tanana terrane, Alaska: Geological Society of America Bulletin, v. 116, p. 989-1015.

Eppinger, R.G., Briggs, P.H., Dusel-Bacon, C., Giles, S., Gough, L.P., Hammarstrom, J.M., and Hubbard, B.E., 2007, Environmental geochemistry at Red Mountain, an unmined volcanogenic massive sulphide deposit in the Bonnifield district, Alaska Range, east-central Alaska: Geochemistry, Exploration, Environment, Analysis, v. 7, issue 3, in press.

Foster, H.L., Keith, T.E.C., and Menzie, W.D., 1994, Geology of the Yukon-Tanana area of east-central Alaska: in Plafker, G. and Berg, H.C., eds., The Geology of Alaska: Boulder, CO, Geological Society of America, The Geology of North America (DNAG), v. G-1, p. 205-240.

Fujisada, H., 1995, Design and performance of ASTER instrument: Proceedings of SPIE, the International Society for Optical Engineering 2583, p. 16-25.

Gilbert, W.G., 1977, General geology of the Healy D-1 and southern Fairbanks A-1 quadrangles, Alaska: Alaska Division of Geological and Geophysical Surveys Open-file Report 105, scale $1: 63,360$.

Gillespie, A. R., Kahle, A. B., and Walker, R. E., 1986, Color enhancement of highly correlated images. I. Decorrelation and HSI contrast stretches: Remote Sensing of Environment, v. 20, p. 209-235.

Green, A.A., Berman, M., Switzer, B., and Craig, M.D., 1988, A transformation for ordering multispectral data in terms of image quality with implications for noise removal: IEEE Transactions on Geoscience and Remote Sensing, v. 26, p. 65-74.

Harsanyi, J.C., and Chang, C., 1994, Hyperspectral image classification and dimensionality reduction, an orthogonal subspace projection approach: IEEE Transactions on Geoscience and Remote Sensing, v. 32, p. 770-785.

Lowell, J.D., and Guilbert, J.M., 1970, Lateral and vertical alteration-mineralization zoning in porphyry ore deposits: Economic Geology, v. 65, p. 373-408.

Lydon, J.W., 1984, Volcanogenic massive sulphide deposits, Part 1, a descriptive model: Geoscience Canada, v. 11, p.195-202.

Mars, J.C., and Rowan, L.C., 2006, Regional mapping of phyllic- and argillic-altered rocks in the Zagros magmatic arc, Iran, using Advanced Spaceborne Thermal Emission and Reflection Radiometer (ASTER) data and logical operator algorithms: Geosphere, v. 2, no.3, p. 161-186.

McLeod, R.L., and Stanton, R.L., 1984, Phyllosilicates and associated minerals in some Paleozoic stratiform sulfide deposits of Southeastern Australia: Economic Geology, v. 79, p. 1-22. 
McLeod, R.L., 1985, Preliminary observations of kaolinite in a volcanogenic massive sulphide deposit of Permian age: TMPM Tschermaks Min. Petr. Mitt., v. 34, p. 261-269.

McLeod, R.L., 1987, Alteration associated with volcanogenic sulphide ores at Mount Chambers, Queensland, Australia: Trans. Instn. Min. Metall. (sect. B: Appl. earth sci.), v. 96, p. B117-B127.

McLeod, R.L., Gabell, A.R., Green, A.A., and Gardavsky, V., 1987, Chlorite infrared spectral data as proximity indicators of volcanogenic massive sulphide mineralisation, In Pacific Rim Congress Proceedings, 26-29 August 1987, Queensland, Australia, p. 321-324.

Newberry, R.J., Crafford, T.C., Newkirk, S.R., Young, L.E., Nelson, S.W., and Duke, N.A., 1997, Volcanogenic massive sulfide deposits of Alaska: Economic Geology Monograph 9, p. 120-150.

Nokleberg, W.J., Plafker, G., and Wilson, F.H., 1994a, Geology of south-central Alaska: in Plafker, G. and Berg, H.C., eds., The Geology of Alaska: Boulder, CO, Geological Society of America, The Geology of North America (DNAG), v. G-1, p. 311-365.

Nokleberg, W.J., plus 40 co-authors., 1994b, Metallogeny and major mineral deposits of Alaska: in Plafker, G. and Berg, H.C., eds., The Geology of Alaska: Boulder, CO, Geological Society of America, The Geology of North America (DNAG), v. G-1, p. 855-903.

Rogers, R.K., and Schmidt, J.M., 2003, Alaska Resource Data File (ARDF), Talkeetna Mountains quadrangle, Alaska: U.S. Geological Survey Open-file Report 03-457, 293 p.

Rowan, L.C., Hook, S.J., Abrams, M.J., and Mars, J.C., 2003, Mapping hydrothermally altered rocks at Cuprite, Nevada, using the Advanced Spaceborne Thermal Emission and Reflection Radiometer (ASTER), A new satellite-imaging system: Economic Geology, v. 98, p. 1019-1027.

Rowan, L.C., and Mars, J.C., 2003, Lithologic mapping in the Mountain Pass, California area using Advanced Spaceborne Thermal Emission and Reflection Radiometer (ASTER) data, Remote Sensing of Environment, v. 84, p. 350-366.

Silberling, N.J., Jones, D.L., Monger J.W.H., Coney, P.J., Berg, H.C., and Plafker, G., 1994, Lithotectonic terrane map of Alaska and adjacent part of Canada, in Plafker, G. and Berg, H.C., eds., The Geology of Alaska: Boulder, CO, Geological Society of America, The Geology of North America (DNAG), v. G-1, scale 1:2,500,000.

Singer, D.A., Csejtey, Béla, Jr., and Miller, R.J., 1978, Map and discussion of the metalliferous and selected nonmetalliferous mineral resources of the Talkeetna Mountains Quadrangle, Alaska: U.S. Geological Survey Open-file Report 78-558-B, incl. scale 1:250,000 map

Singer, D.A., 1993, Basic concepts in three-part quantitative assessments of undiscovered mineral resources: Nonrenewable Resources, v. 2, no. 2, p. 69-81.

Stevens, D.L., 2001, Alaska Resource Data File (ARDF), Healy quadrangle, Alaska: U.S. Geological Survey Open-file Report 01-109, 441 p. 
United States Geological Survey, 2002, Assessment of Undiscovered Deposits of Gold, Silver, Copper, Lead, and Zinc in the United States: U. S. Geological Survey Open-file Report 02-198, A PDF recompilation of USGS OFR 96-96 and Circular 1178, USGS National Mineral Assessment Team.

Wahrhaftig, C., 1970a, Geologic map of the Healy D-2 quadrangle, Alaska: U. S. Geological Survey Geologic Quadrangle Map GQ-804, scale 1:63,360.

Wahrhaftig, C., 1970b, Geologic map of the Healy D-3 quadrangle, Alaska: U. S. Geological Survey Geologic Quadrangle Map GQ-805, scale 1:63,360. 


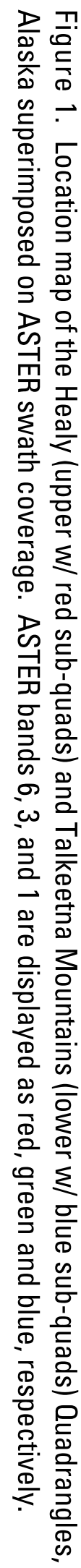

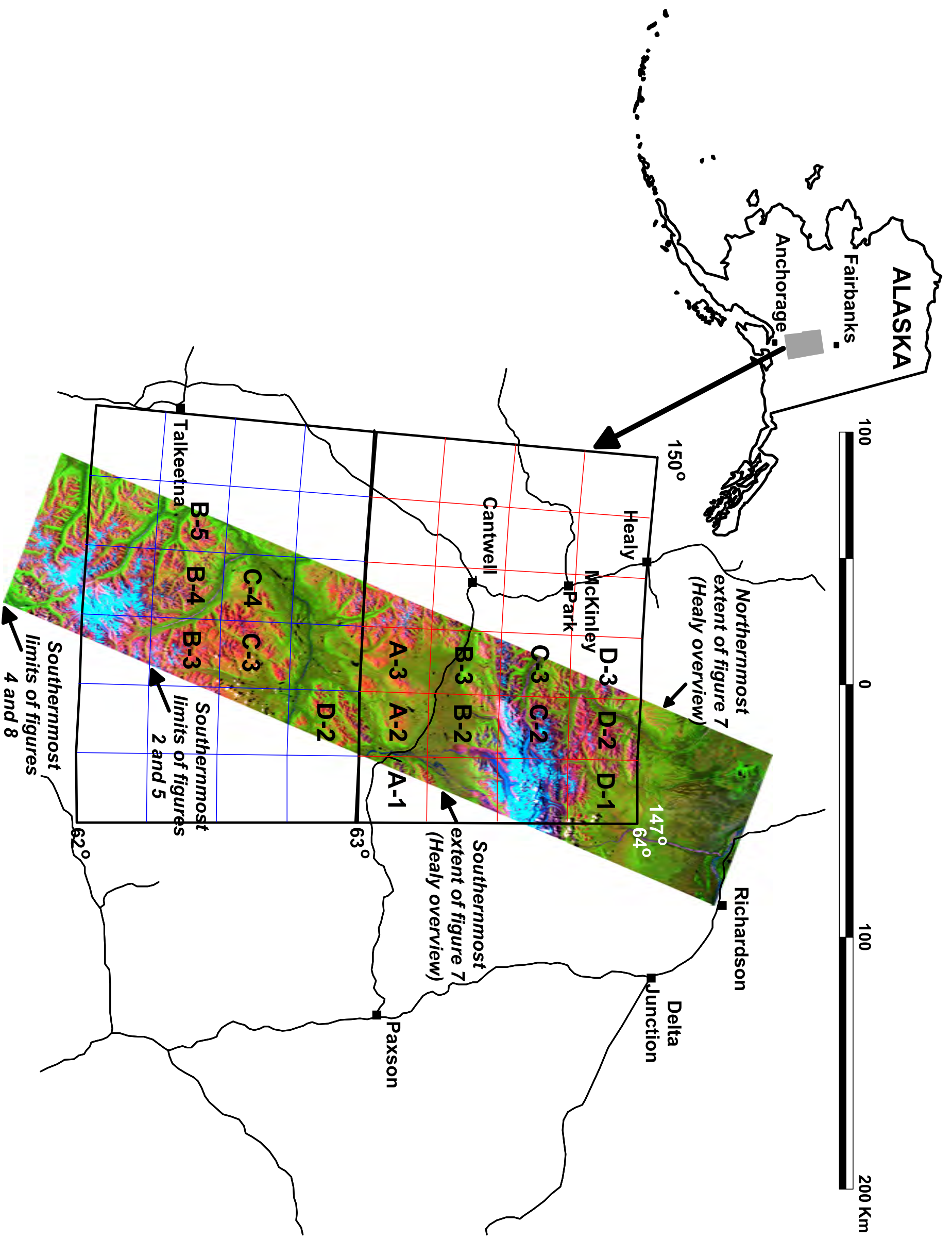




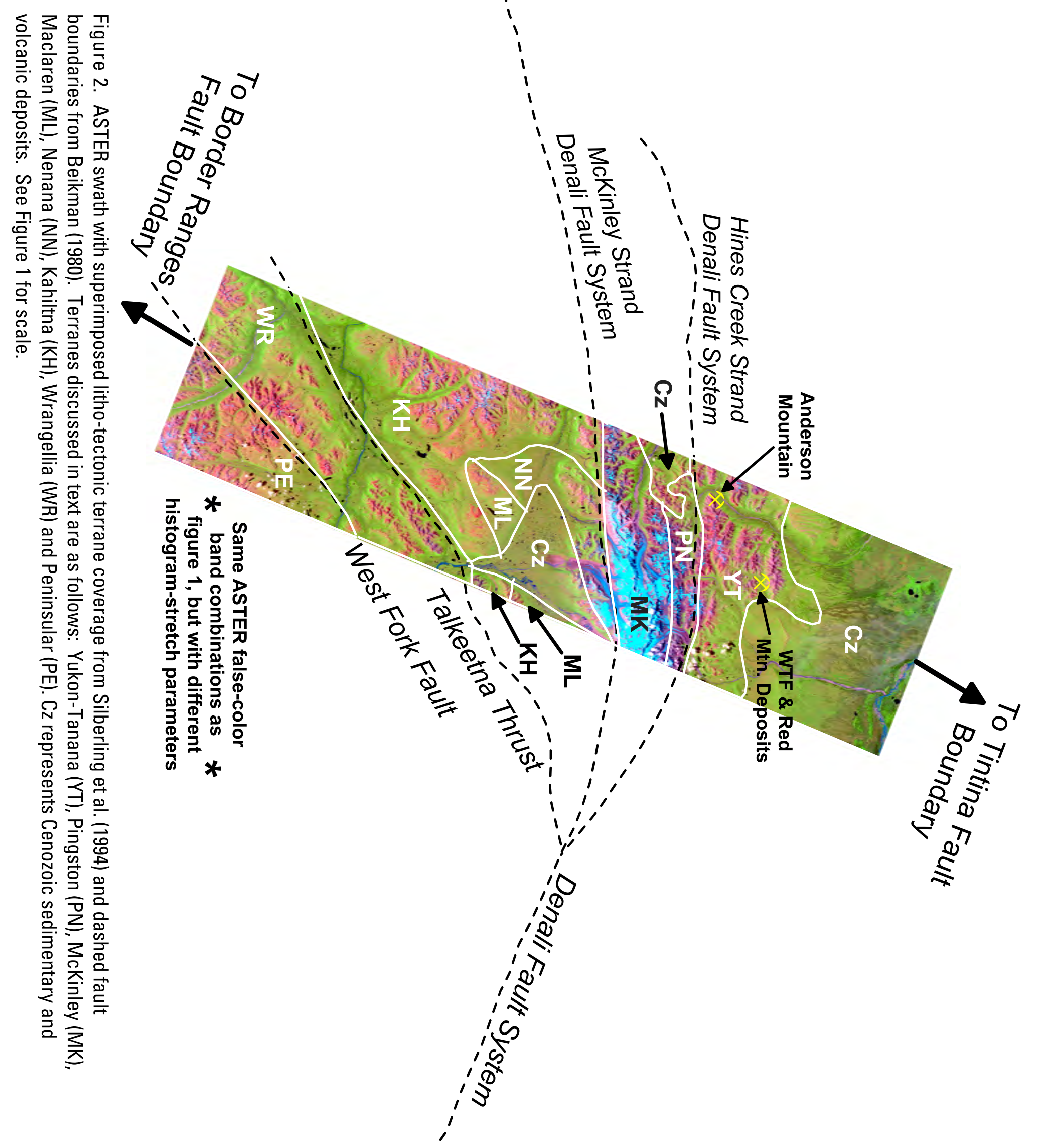




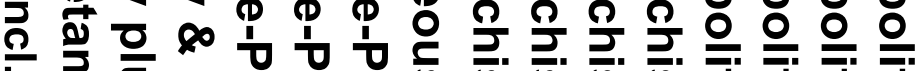

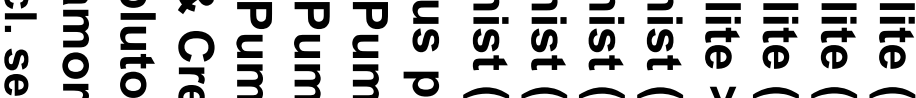

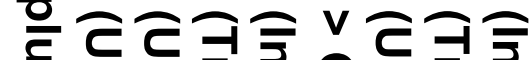

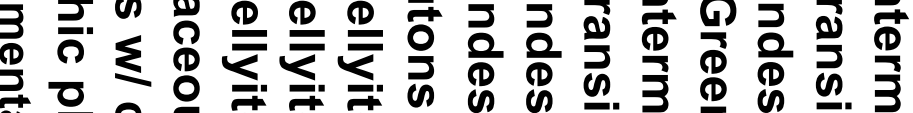

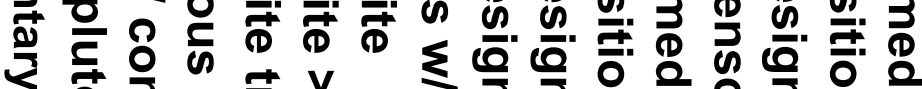

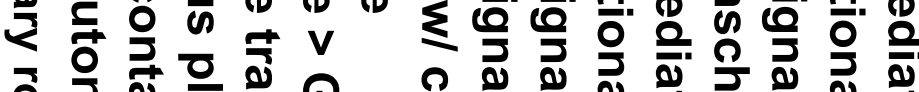

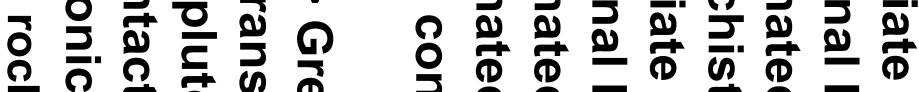

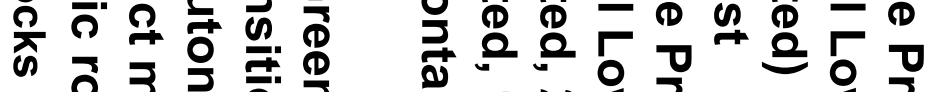

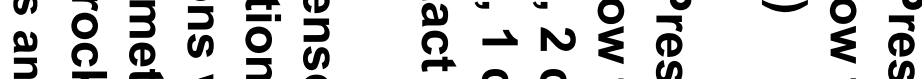

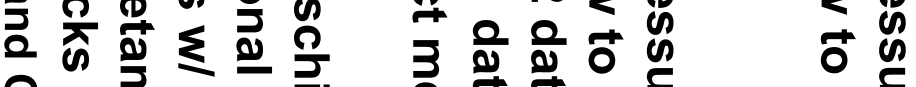

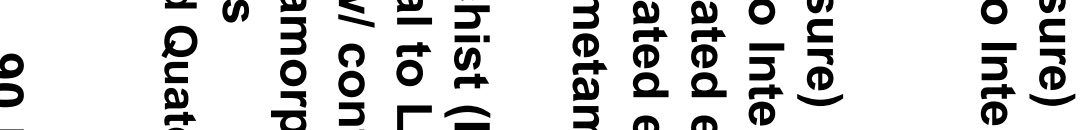

족

흘

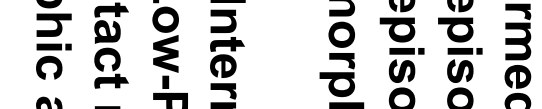

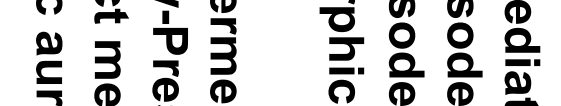

ต $\quad$ D

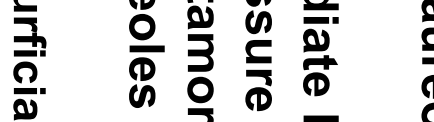

옥

(1)

ำ $\frac{9}{8}$

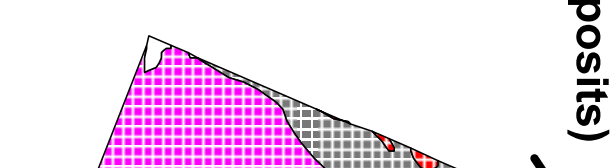

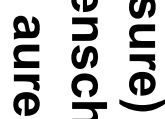

ㅇํㄹ ำ

号

$\frac{7}{0}$

吕
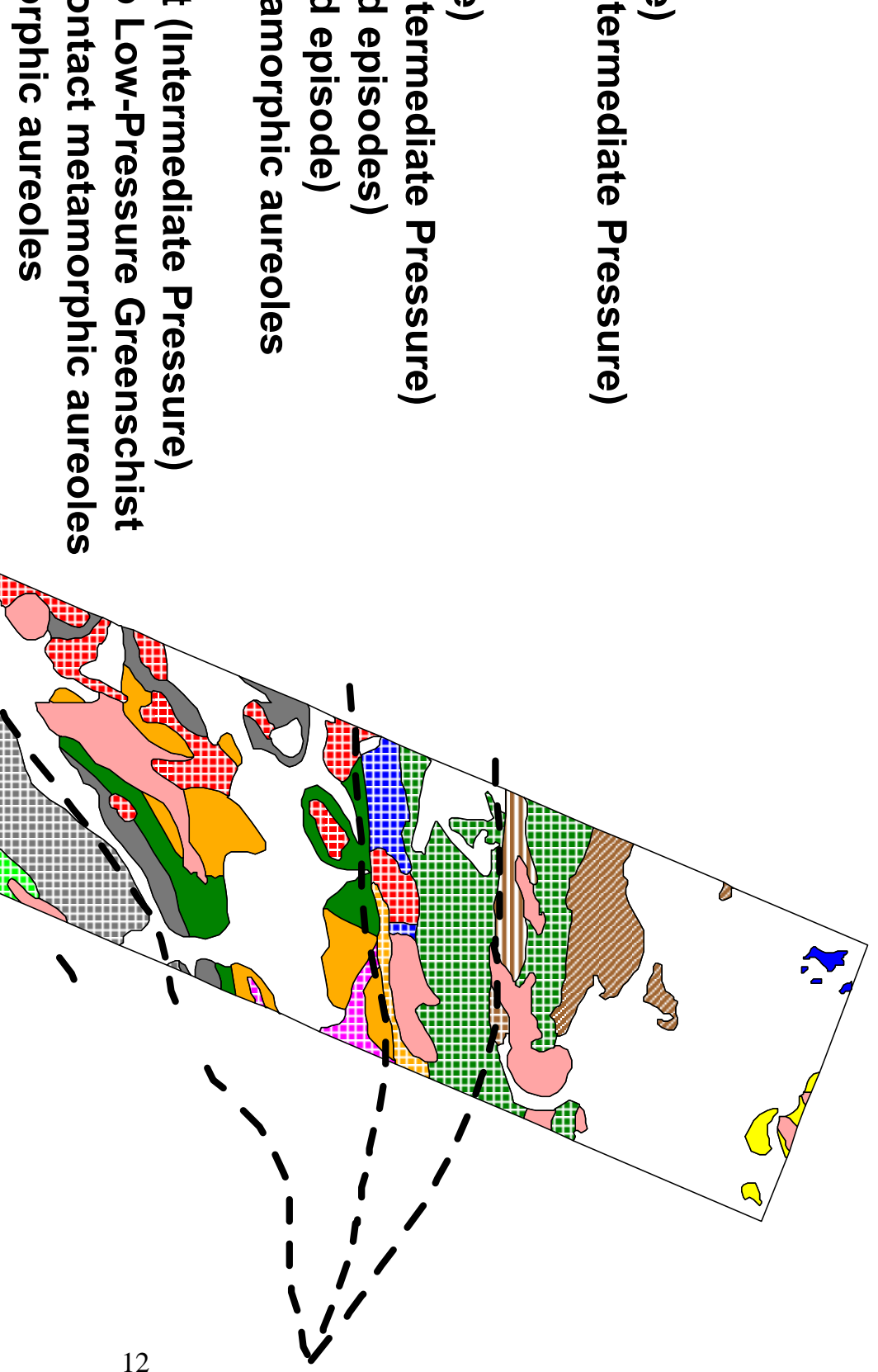


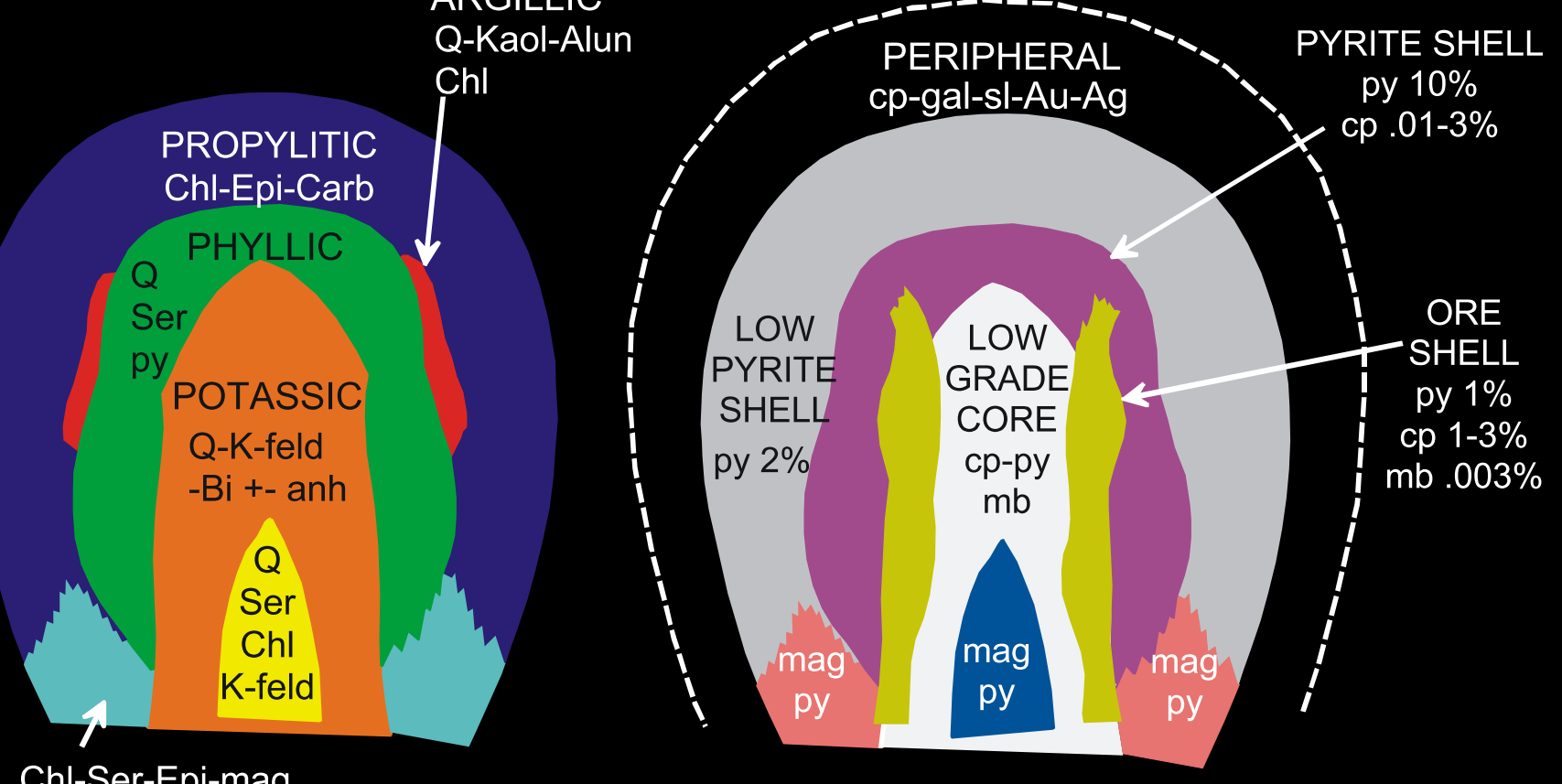

Chl-Ser-Epi-mag

(Modified from Lowell and Guilbert, 1970)

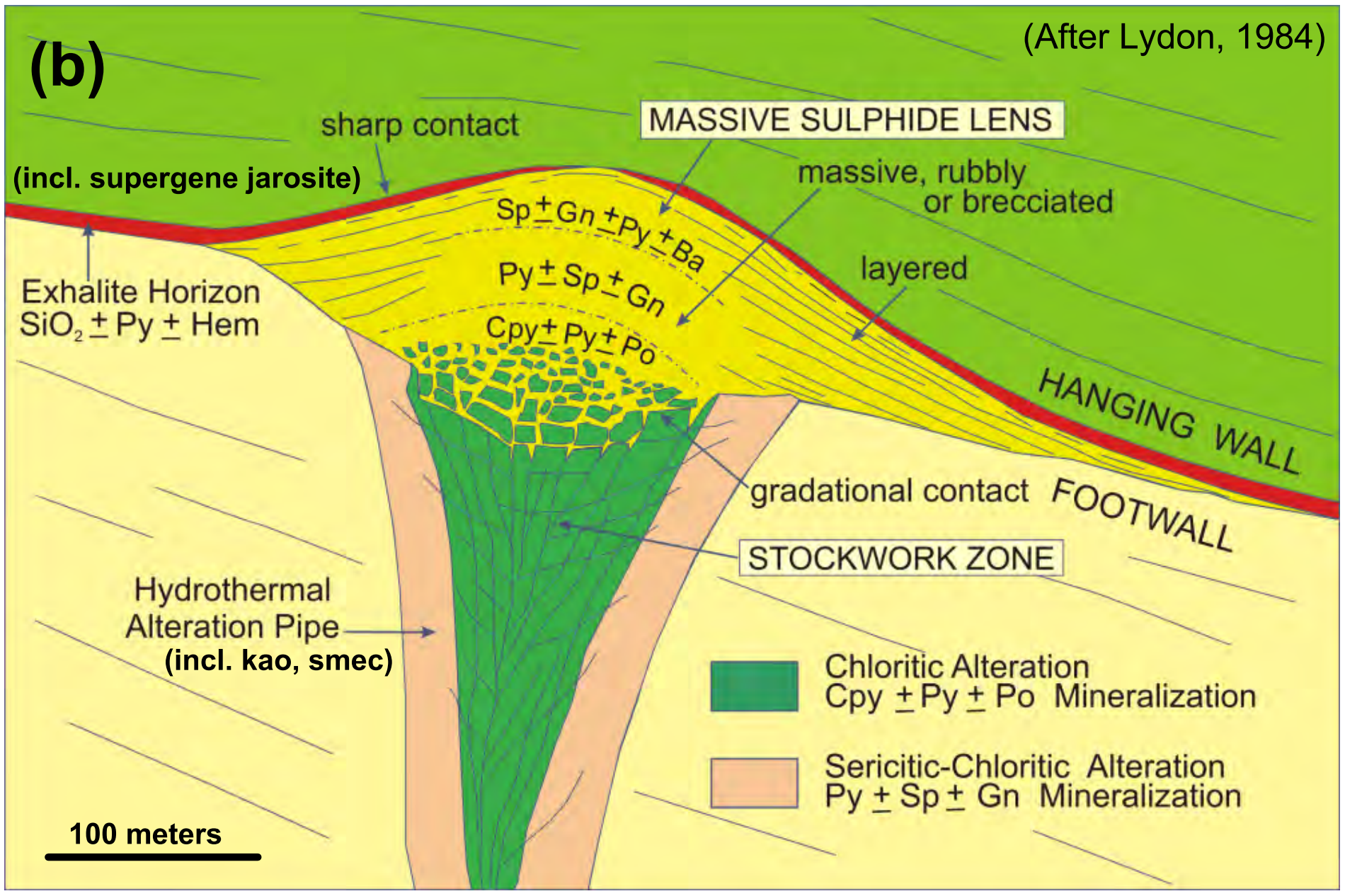

Figure 4. Mineral deposit models for (a) Porphry Cu-Au-Mo and (b) Kuroko-type volcanogenic massive sulfides (VMS), useful for remote sensing exploration using ASTER (See Cox and Singer, 1986 models 20c/21a and 28a respectively, for detailed characteristics and descriptions of both depsoit types). 


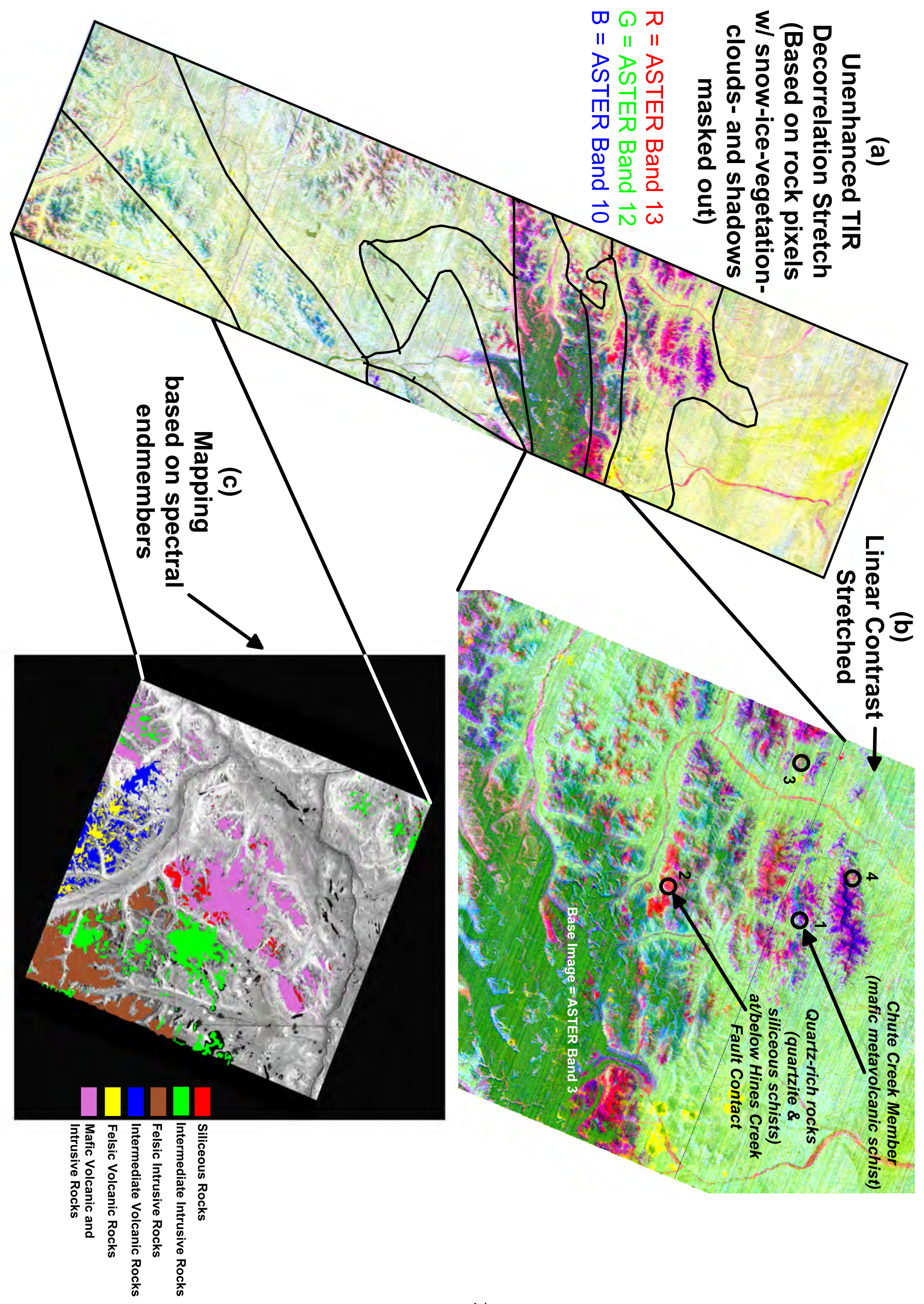




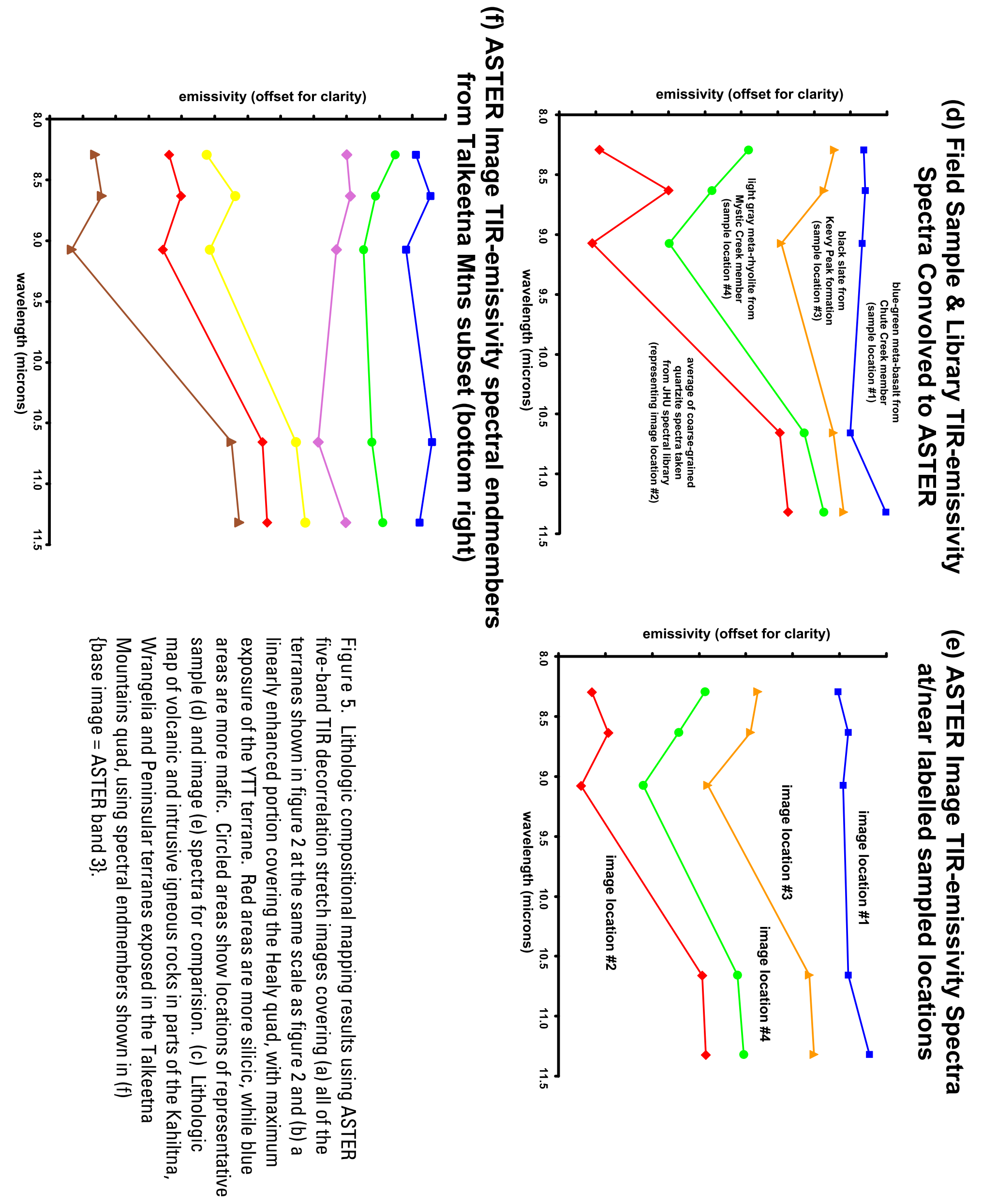


(a) VNIR-SWIR Image Endmember Spectra

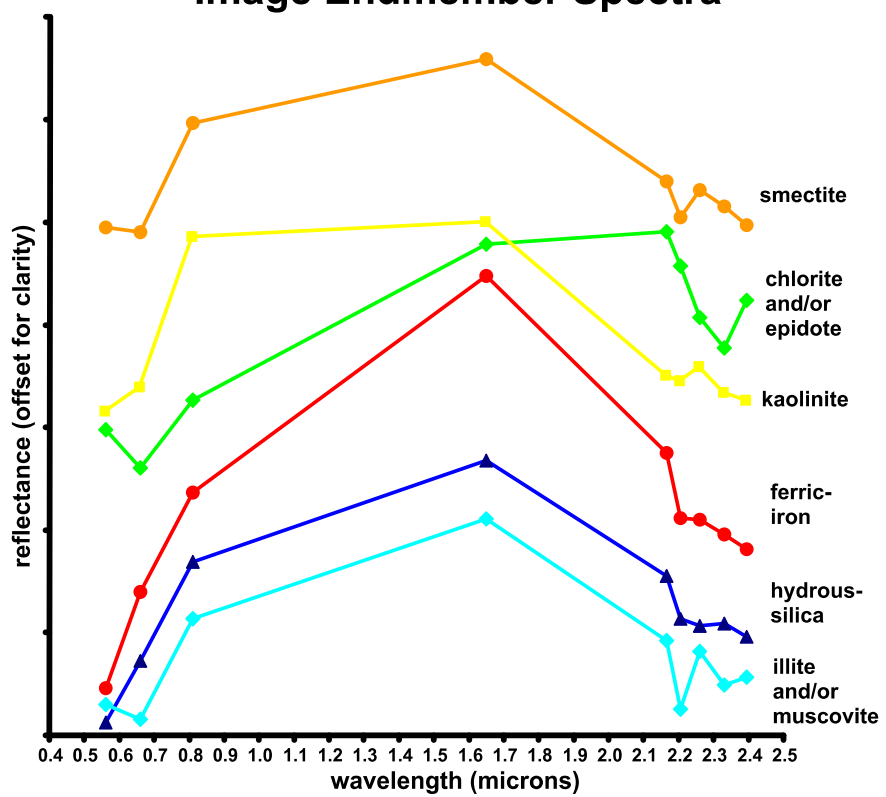

(c) VNIR-SWIR Laboratory ferric-iron mineral spectra

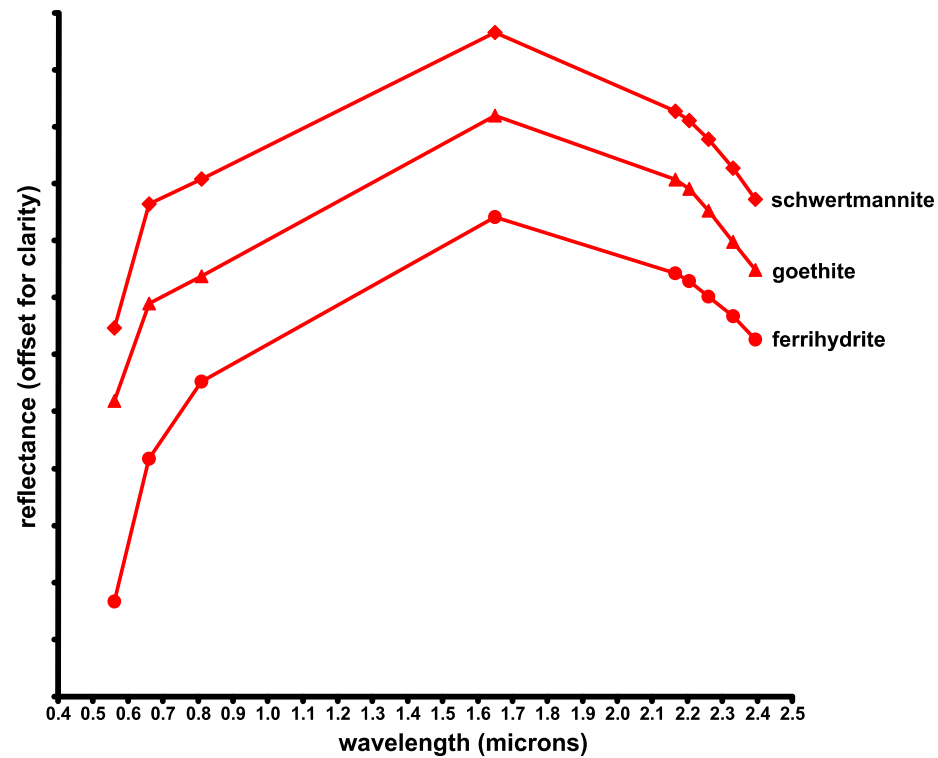

(e) VNIR-SWIR

Laboratory clay and mica mineral spectra

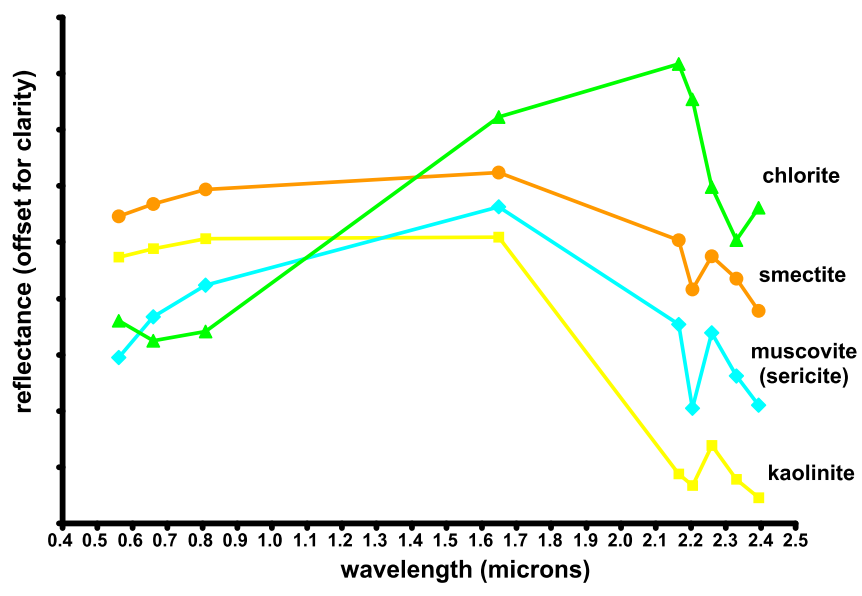

(b) VNIR-SWIR Image Endmember Spectra

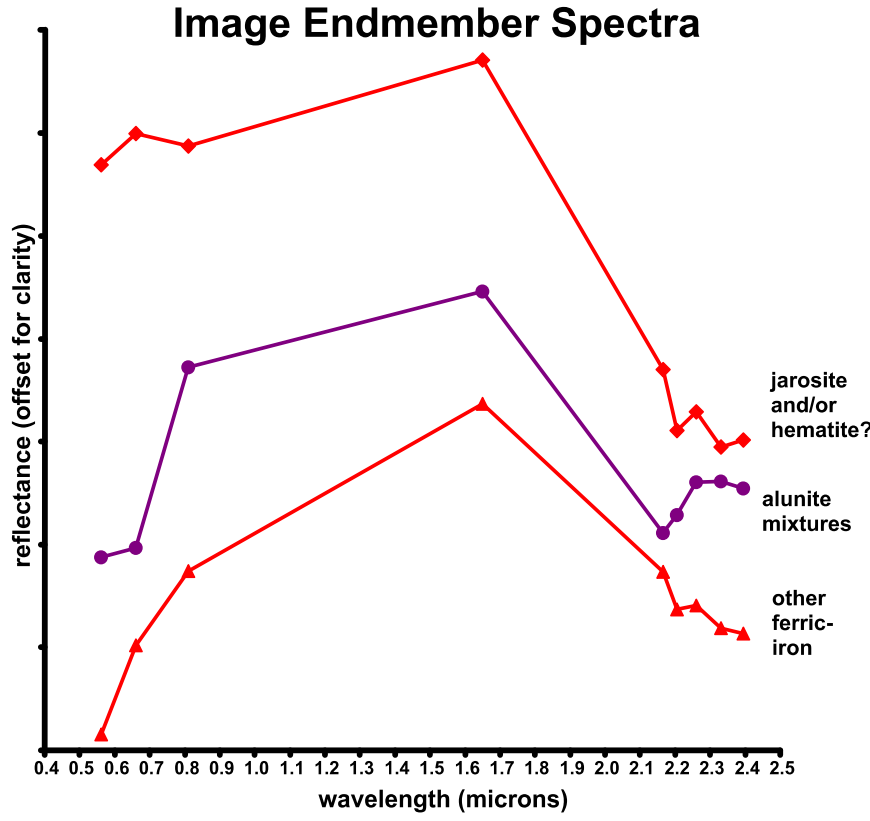

(d) VNIR-SWIR

Laboratory sulfate-silica mineral spectra

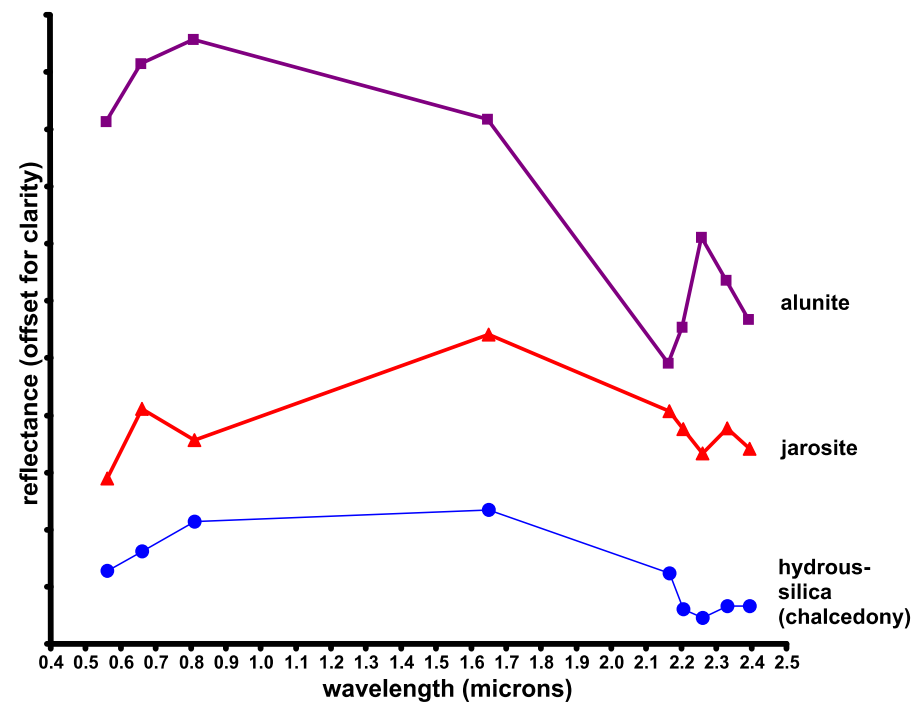

Figure 6. VNIR-SWIR image endmember spectra (a) and (b), and laboratory spectra of pure mineral types such as ferric-iron (c), sulfates and silica (d) and clay and white mica (e) for comparison. 


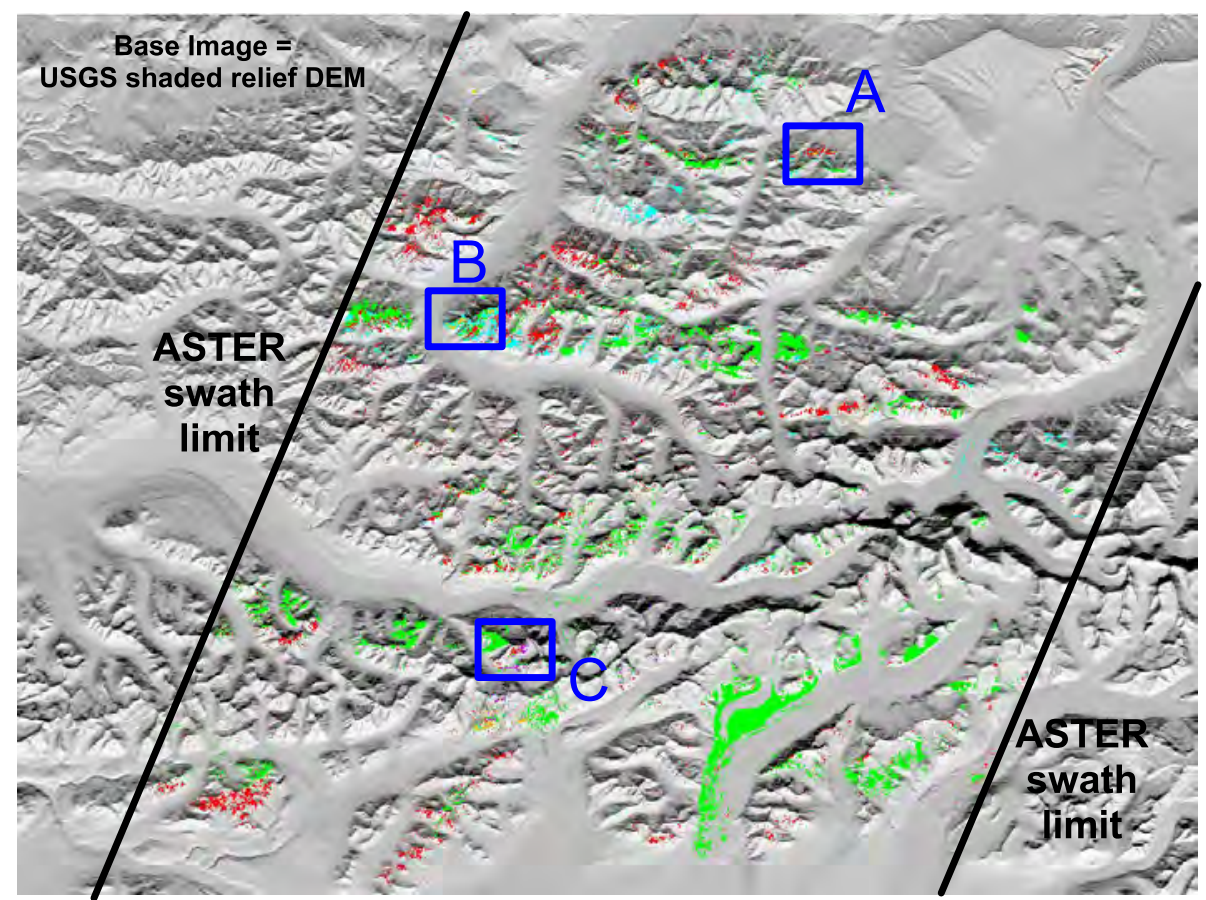

1:425,000 scale

mineral map:

Red $=$ ferric-iron

Green $=$ chlorite or epidote

Cyan = muscovite or illite

$1: 25,000$ scale

subsets:

Red = ferric-iron

Green $=$ chlorite or epidote

Cyan = muscovite or illite

Purple $=$ alunite

Orange = smectite

Yellow = kaolinite

blue $=$ hydrous silica
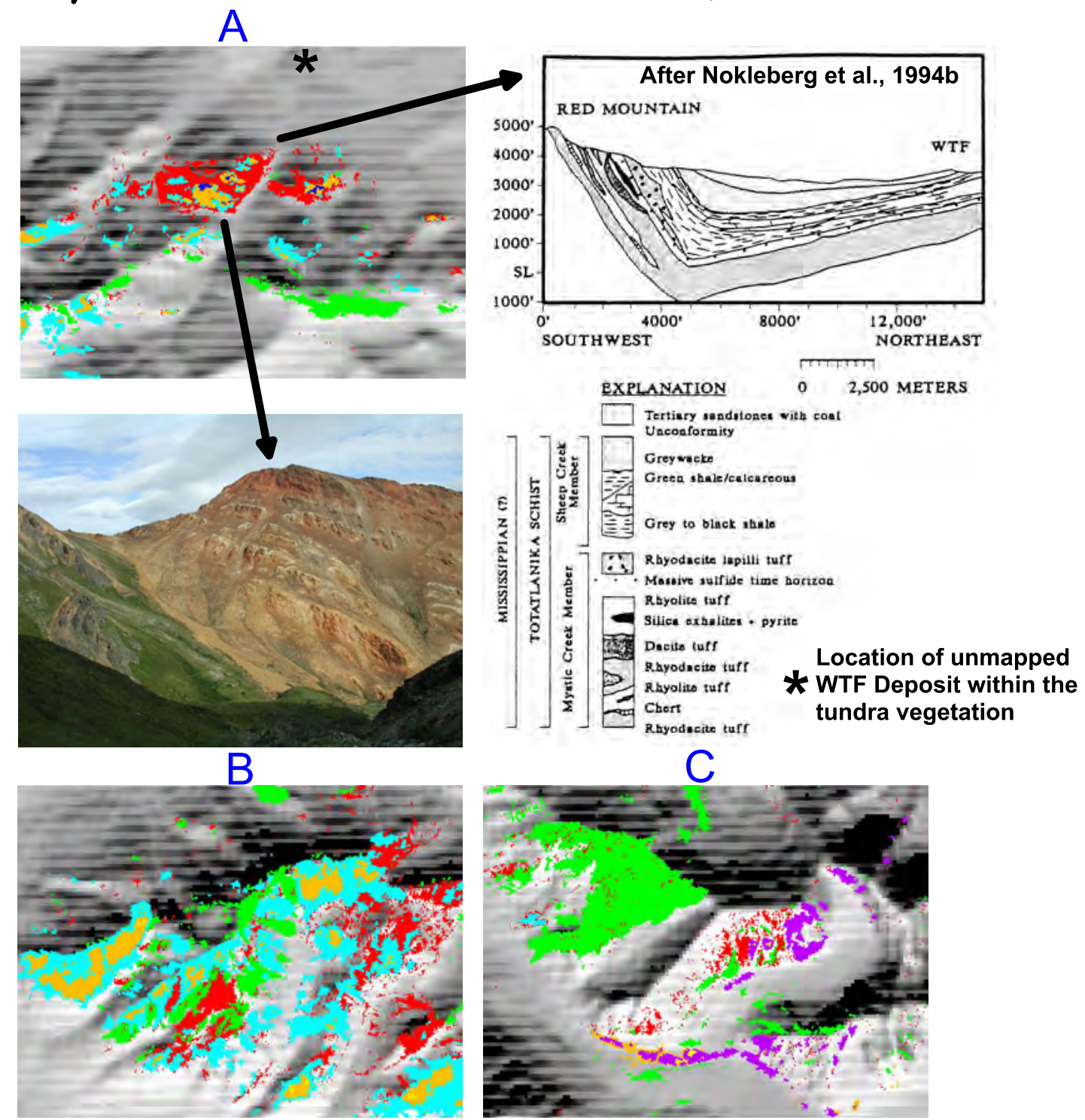

Figure 7. 1:425,000 scale map of the Healy Quadrangle, Alaska (main overview) showing alteration mineral zones mapped at a scale of 1:25,000 for the (a) Red Mountain and WTF massive sulfide deposits (see also fig. 2), (b) Anderson Mountain massive sulfide deposits (see also fig. 2), and (c) area of possible alunite occurrence at Nenana mountain in the McKinley terrane. Also shown are photo and stratigraphic section of the Red Mountain and WTF deposits, below and to the left of subset (a) respectively. 


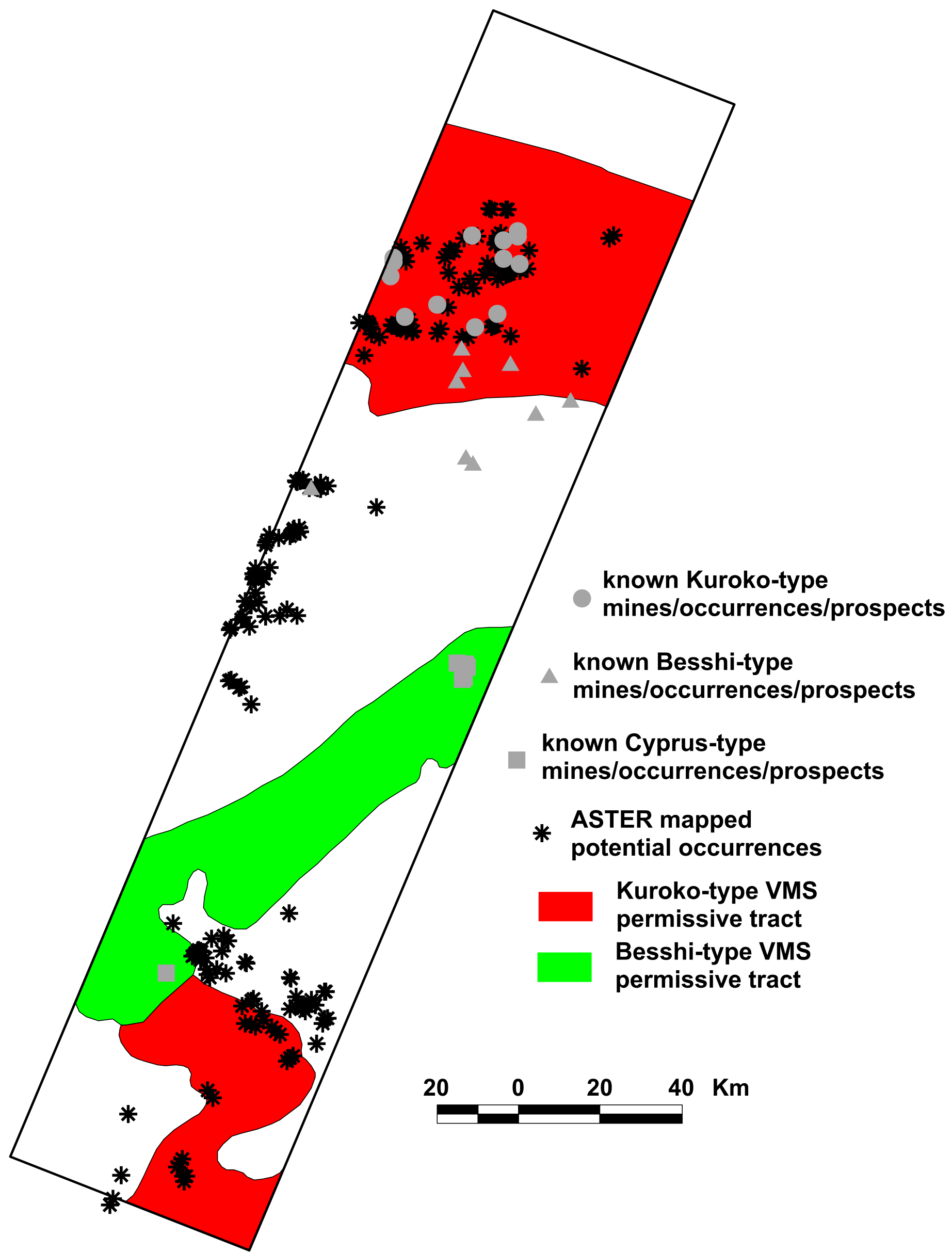

Figure 8. Permissive tracts for Kuroko- and Besshi-type VMS deposits, with superimposed locations of actual mines, prospects and occurences, and ASTER derived VMS suspected targets. Permissive tract boundaries are from USGS (2002). 